\title{
Regulating receptor editing
}

do.NF- $\kappa B$...
does seem to
have a role in
preventing the
development
of self-reactive
B cells by
modulating
receptor
editing.

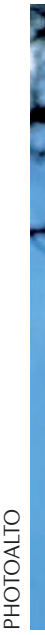

When the $\mathrm{B}$ cell receptor (BCR) on an immature $B$ cell recognizes self antigen, receptor editing occurs during which immunoglobulin light chain rearrangements continue in order to change the BCR specificity. Previous studies addressing the role of nuclear factor- $\mathrm{KB}$ (NF- $\kappa \mathrm{B})$ in $\mathrm{B}$ cell development have yielded conflicting results. Now, the results of a study by Cadera $e t$ al. point to a possible role for NF- $\mathrm{kB}$ in receptor editing.

The authors took advantage of the fact that NF- $\mathrm{KB}$ directly regulates the activity of inhibitor of NF- $\mathrm{KB} \alpha$ (IKBa). So, they looked at the activity of NF- $\mathrm{kB}$ using a targeted mutant mouse in which $\beta$-galactosidase $(\beta$-gal) expression reports the activity

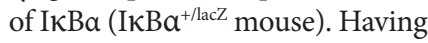

first confirmed that known activators of NF- $\kappa \mathrm{B}$ also induced $\beta$-gal expression, the authors looked at $\beta$-gal expression during B cell development from bone marrow cells. Stage-specific $\beta$-gal expression was observed, with a peak of expression in pre-B cells. Using real-time reverse transcription PCR to quantify various light chain locus transcripts, they found that $\beta$-gal ${ }^{+}$pre-B cells had increased light chain replacement or editing gene rearrangements compared with $\beta$-gal ${ }^{-}$pre-B cells. Furthermore, retroviral infection of an I $\mathrm{B} B \alpha$ superrepressor (which inhibits the activation of NF- $\kappa B$ through the classical pathway) in primary bone marrow cell cultures resulted in diminished immunoglobulin light $\lambda$-chain $(\operatorname{Ig} \lambda)$ rearrangements and reduced IgK accessibility, suggesting that inhibiting NF- $\kappa \mathrm{B}$ can downregulate immunoglobulin light chain gene rearrangement. Various markers of receptor editing, including recombining sequence gene rearrangements (which are considered a hallmark of receptor editing) and secondary Igא gene rearrangements, were observed in $\beta$-gal ${ }^{+}$pre-B cells and not $\beta$-gal ${ }^{-}$pre-B cells, showing that $I \kappa B \alpha$ expression correlates with receptor editing.

To confirm that NF- $\kappa \mathrm{B}$ has a role in receptor editing, I $\mathrm{I} B \alpha^{+/ l a c Z}$ mice were crossed with various $\mathrm{BCR}$ knock-in mice to generate mice expressing either a self-specific BCR or an innocuous BCR. In the two mouse lines expressing a self-specific BCR, in which the developing B cells are almost all undergoing receptor editing, most of the $\mathrm{B}$ cells expressed $\mathrm{I} \kappa \mathrm{B} \alpha$, as measured by $\beta$-gal expression. By contrast, most of the B cells from the mice expressing an innocuous BCR, in which receptor editing was not needed, did not express the $\beta$-gal reporter gene.

So, how might NF- $\kappa \mathrm{B}$ mediate the regulation of receptor editing? Transcripts of many NF- $\kappa \mathrm{B}$ target genes were quantified using reverse transcription PCR. This showed a fourfold increase in interferonregulatory factor 4 (IRF4) transcripts in $\beta$-gal ${ }^{+}$pre-B cells compared with $\beta$-gal ${ }^{-}$pre- $B$ cells. This implies that NF- $\kappa B$ could be acting through IRF4 which has previously been shown to have a role in pre- $\mathrm{B}$ cell development and receptor editing.

This study shows that although NF- $\kappa \mathrm{B}$ may not have an essential role in B cell development per se, it does seem to have a role in preventing the development of self-reactive B cells by modulating receptor editing.

Elaine Bell

ORIGINAL RESEARCH PAPER Cadera, E. J. et al. $\mathrm{NF}-\kappa \mathrm{B}$ activity marks cells engaged in receptor editing.J. Exp. Med. 6 Jul 2009 (doi:10.1084/ jem.20082815) 